\section{Acid Etching and Surface Coating of Glass-Fiber Posts: Bond Strength and Interface Analysis}

\author{
Doglas Cecchin ${ }^{1}$, Ana Paula Farina' ${ }^{1}$, Rafael Pino Vitti², Rafael Ratto Moraes ${ }^{3}$, \\ Ataís Bacchi ${ }^{4}$, Aloísio Oro Spazzin ${ }^{4}$
}

\begin{abstract}
The aim of this study was to evaluate the bond strength of a composite resin to glassfiber post (GFP) treated or not with phosphoric acid, silane coupling agent, and unfilled resin. GFPs were etched or not with $37 \%$ phosphoric acid and different surface coating applied: silane coupling agent, unfilled resin, or both. Composite resin blocks were built around a 4-mm height on the GFP. Unfilled resin (20 s) and composite resin (40 s) were light activated by a light-emitting diode unit. The specimens were stored in distilled water at $37^{\circ} \mathrm{C}$ for $24 \mathrm{~h}$. Microtensile bond test was performed using a mechanical testing machine until failure $(n=10)$. The data were analyzed using two-way ANOVA followed by Student-Newman-Keuls' test $(p<0.05)$. Failure modes were classified as adhesive, mixed, or cohesive failures. Additional specimens $(n=3)$ were made to analyze the bonded interfaces by scanning electron microscopy. The statistical analysis showed the factor 'surface coating' was significant $(p<0.05)$, whereas the factor 'HP etching' $(p=0.131)$ and interaction between the factors ( $p=0.171)$ were not significant. The highest bond strength was found for the silane and unfilled resin group $(p<0.05)$. A predominance of adhesive and cohesive failures was found. Differences regarding the homogeneity and thickness of the unfilled resin layer formed by different GFP surface treatments were observed. The application of silane and unfilled resin can improve the bond strength between GFP and resin composite.
\end{abstract}

'Department of Restorative Dentistry, Dental School, UPF - Universidade de Passo Fundo, Passo Fundo, RS, Brazil ${ }^{2}$ Department of Prosthodontics, Dental School, UNITAU - Universidade de Taubaté, Taubaté, SP, Brazil ${ }^{3}$ Department of Restorative Dentistry, Dental School, UFPel - Universidade Federal de Pelotas, Pelotas, RS, Brazil ${ }^{4}$ Department of Prosthodontics, Dental School, IMED - Faculdade Meridional, Passo Fundo, RS, Brazil

Correspondence: Aloísio Oro Spazzin, Rua Senador Pinheiro, 304, Bairro Rodrigues, 99070-220 Passo Fundo, RS, Brasil. Tel: +55-54-3045-6100. e-mail: aospazzin@yahoo.com.br

\section{Introduction}

Several clinical failures of endodontically treated teeth (e.g. root fracture) are often associated with post cementation flaws (1). To obtain the clinical success of the prosthetic treatment, it is essential that posts show physical properties as rigidity similar to that of dentin, promoting a correct distribution of occlusal forces along the tooth (2). The glass-fiber posts (GFPs) have two important advantages in relation to other types of posts: (1) the elastic modulus close to that of dentin, and (2) the core build-ups cemented by an adhesive technique $(2,3)$. These characteristics may improve the retention as well as the mechanical performance of the restored teeth endodontically treated (4). However, there are still several difficulties with using GFPs. Bonding to resin core buildup is a complex procedure due to the sensitivity of the technique (5). Moreover, different restorative materials can be used in clinical practice, so it is difficult to predict the clinical performance of restorations anchored by GFPs in relation to incompatibilities between adhesives and resin cements or composites (6).

In order to improve the bond strength between the GFPs and the resin composite, various surface treatment procedures have been investigated using mechanical (sandblasting) or chemical agents (silanization, acid etching, silica coating, bonding agents) (7-9). Some of these treatments can increase the post surface roughness and wettability, thus enhancing the interlocking between GFPs and resin composite (10). The ability of phosphoric acid (HP) to change GFP surface topography by an etching procedure results in increased contact surface and improves the interaction between GFP and resin composite (11). In order for the energy of contact surface generated by etching acid to be optimized, the resin agents need sufficient wettability to completely infiltrate the irregularities (11).

The prosthodontic treatment using post and core system is widely used in dentistry. Nowadays, the metallic posts have been replaced by non-metallic posts, as the epoxy resin posts reinforced with glass fibers (GFPs) (12). Studies using GFPs has shown satisfactory results for the physico-mechanical properties, contributing to the success of prosthodontic treatment $(2,5,10,13)$.

Eames et al. (14) suggested the use of a silane coupling agent in dentistry. The most commonly used silane for dental applications is a pre-hydrolyzed monofunctional $\gamma$-metha cryloxypropyltrimethoxysilane diluted in an ethanol-water solution. The silane coupling is marketed in a pre-hydrolyzed form (one bottle) or in a form where hydrolysis can occur by mixing silane and acid (two bottles) (15). Silanes are bifunctional molecules with one end of the molecule capable of reacting with inorganic glass fiber and the other with organic resin. Silanization is the technique most often 
used to improve the bond strength of GFPs to the resin composite (10). This treatment increases the wettability and forms a covalent bond with both the GFPs and the resin composite (16). The action mechanism of silane relies on the formation of bonds between its functional alkoxy groups and the $\mathrm{OH}$-covered inorganic fibers (10).

However, the adhesive cementation of GFPs using silane coupling agents to improve the bonding of resin is a controversial issue (17). Some studies reported that silanization does not improve the bond strengths of resin composite to GFPs $(8,17)$, whereas others have demonstrated an increasing effect on bond strengths via silanization $(16,18)$. Another subject of controversy is the use of a polymerizable bonding agent after silane. The use of a bonding agent could provide a better mechanical interlocking with the GFPs, since the silane forms a very thin layer over the surface. Thus, there is a lack of knowledge regarding the influence of different surface treatments on bond strength to GFPs, mainly about the use of silane.

The aim of this study was to evaluate the bond strength of a composite resin to GFP treated or not with phosphoric acid, silane coupling agent, and bonding agent. The hypotheses tested were that (i) phosphoric acid, (ii) the silane treatment, and (iii) the bonding agent would enhance the bond strength to the GFPs.

\section{Material and Methods}

\section{Specimen Preparations}

Customized rectangular ( $6 \times 5 \mathrm{~mm}, 2 \mathrm{~mm}$ thick) GFPs were obtained from Angelus (Londrina, PR, Brazil). The bar geometry was important to allow obtaining specimens on a flat post surface. The bars were submitted to wet polishing using 400-, 600-, 1200-, and 2000-grit silicon carbide papers (Norton SA, São Paulo, SP, Brazil) to obtain flat surfaces on both sides. The specimens were ultrasonically cleaned in distilled water for $10 \mathrm{~min}$ and dried with compressed air. The materials and application mode used for the etching and surface coating are presented in Table 1. The GFPs were either etched or not, and different surface coating applied: none, silane, unfilled, silane+unfilled resin .

The unfilled resin was light activated for $20 \mathrm{~s}$ using a light-emitting diode unit (UltraLume 5, Ultradent Products, South Jordan, UT, USA) operated at $800 \mathrm{~mW} / \mathrm{cm}^{2}$ of irradiance. The composite resin (Z250 XT; 3M ESPE, St. Paul, MN, USA) was built around the 4-mm height on the GFP; each increment of 1-mm height was light activated for $40 \mathrm{~s}$. For each group, 5 samples were prepared.

\section{Bond Strength Test and Failure Analysis}

The samples were stored in distilled water at $37^{\circ} \mathrm{C}$ for $24 \mathrm{~h}$. For the microtensile bond test, the samples were serially sectioned into sticks with approximately $1-\mathrm{mm}^{2}$ thick of the bond interface using a diamond saw (Isomet, Buehler, Lake Buff, IL, USA). Two sticks of each sample were randomly selected from the central area. These were fixed to a jig using cyanoacrylate glue (Super Bonder Gel, Loctite, Rocky Hill, CT, USA) in a mechanical testing machine (4411; Instron Corp., Canton, OH, USA) and tested until failure $(n=10)$. Bond strength values were calculated in MPa. The data were submitted to a two-way ANOVA (HP etching vs. surface coating) and multiple comparison procedures were carried out by the Student-Newman-Keuls' method $(p<0.05)$. The fractured specimens were examined under optical microscopy at a $40 \times$ magnification. Modes of failure were classified as adhesive failure, mixed failure (remnants of composite and/or bonding agent on the post surface), or cohesive (failure in composite and/or bonding agent).

\section{Scanning Electron Microscopy (SEM) Analysis of the Bonded Interfaces}

In order to observe the morphology of the bonded interfaces, additional specimens $(n=3)$ were obtained and embedded cross-sectionally in epoxy resin, similar to what has been previously described (19). The specimens were wet polished with 600-, 1200-, 1500-, 2000-, and 2500-grit SiC papers followed by polishing with 3, 1, 0.25, and $0.1 \mu \mathrm{m}$ diamond polishing suspensions. Debris was ultrasonically removed for 10 min among each polishing step. The specimens were coated with gold and the cross-section profiles examined by SEM (JEOL JSM-5600LV, Tokyo, Japan) at $15 \mathrm{kV}$, focusing on the depth of etching, micromechanical entanglement, integrity, and homogeneity of the bonding interface.

\section{Results}

Results for the microtensile bond strength test are shown in Table 2. The statistical analysis showed the factor 'surface coating' was significant $(p<0.05)$,
Table 1. Materials, manufacturers and application mode

\begin{tabular}{cc}
\hline Material/Manufacturer & Application mode \\
\hline 37\% phosphoric acid & $\begin{array}{c}\text { Applied for 15 s, washed for 15 and } \\
\text { dried for 30 s with compressed air. }\end{array}$ \\
Condac 37, FGM, Joivinle, SC, Brazil & Applied two thin layers, waited $60 \mathrm{~s}$ \\
Silane coupling agent & and dried for 30 s with a mild air. \\
Silano, Angelus, Londrina, PR, Brazil & Applied a thin coated, dried \\
Unfilled resin & for $5 \mathrm{~s}$ with a mild air and \\
light activated for 20 s.
\end{tabular}


whereas the factor 'HP etching' $(\mathrm{p}=0.131)$ and interaction between the factors $(p=0.171)$ were not significant. All groups showed significantly higher bond strengths when some surface coating was applied $(p<0.05)$. The highest bond strength was found for the combined use of silane and unfilled resin $(p<0.05)$, irrespective of the HP etching. Overall, the acid etch did not present influence on the bond strength, however, when silanization of the post was not carried out, the use of the HP etching before the unfilled resin increased the bond strength between composite resin and GFP $(p=0.05)$.

Distribution of failure modes is presented in Figure 1. A predominance of adhesive failure was detected for the non-etched group and mixed failure for the etched group, irrespective of the use of silane and/or bonding agent. However, the number of mixed failures was higher for both

Table 2. Groups tested and means (standard deviations) for bond strength (MPa)

\begin{tabular}{|c|c|c|c|c|}
\hline \multirow[t]{2}{*}{ HP } & \multicolumn{4}{|c|}{ Surface coating } \\
\hline & None & Silane & $\begin{array}{l}\text { Unfilled } \\
\text { resin }\end{array}$ & $\begin{array}{c}\text { Silane }+ \\
\text { Unfilled resin }\end{array}$ \\
\hline No & $3.9(0.8)^{D, a}$ & $10.3(2.2)^{\text {B,a }}$ & $8.4(3.0)^{c, b}$ & $15.3(4.8) \mathrm{A}, \mathrm{a}$ \\
\hline Yes & $3.6(1.3)^{c, a}$ & $10.4(2.8)^{B, a}$ & $11.1(2.7)^{B, a}$ & $17.3(4.3) \mathrm{A}, \mathrm{a}$ \\
\hline
\end{tabular}

groups (etched and non-etched) where the surface coating was performed using silane and unfilled resin.

Representative SEM images of the bonded interfaces are shown in Figure 2. For the group non-etched when unfilled resin was used as surface coating, a thicker adhesive layer between the post and resin composite can be observed (Figure 2B). Other differences such as depth of etching, micromechanical entanglement, integrity, and homogeneity of the bonding interface were not observed for the other groups.

\section{Discussion}

When a restoration of endodontically treated teeth is performed, many factors can play an important part in the resin bond with the tooth structure. There are three interfaces which need to be considered: the dentin-luting resin, the GFP-luting resin, and the GFP-composite resin interfaces. The bond strength at these interfaces has to be optimized because a weak interface can contribute to failure of the restoration. Thus, a stable and durable bond between the dental materials and GFP is trivial for the clinical success (20).

Several methods were developed for evaluating bond strength. The micro-shear bond test is a common testing method, but it often produces cohesive fracture within the substrate rather than the interface. This occurs due to the generation of complex stress distribution during the test and may lead to erroneous results interpretation (21). The

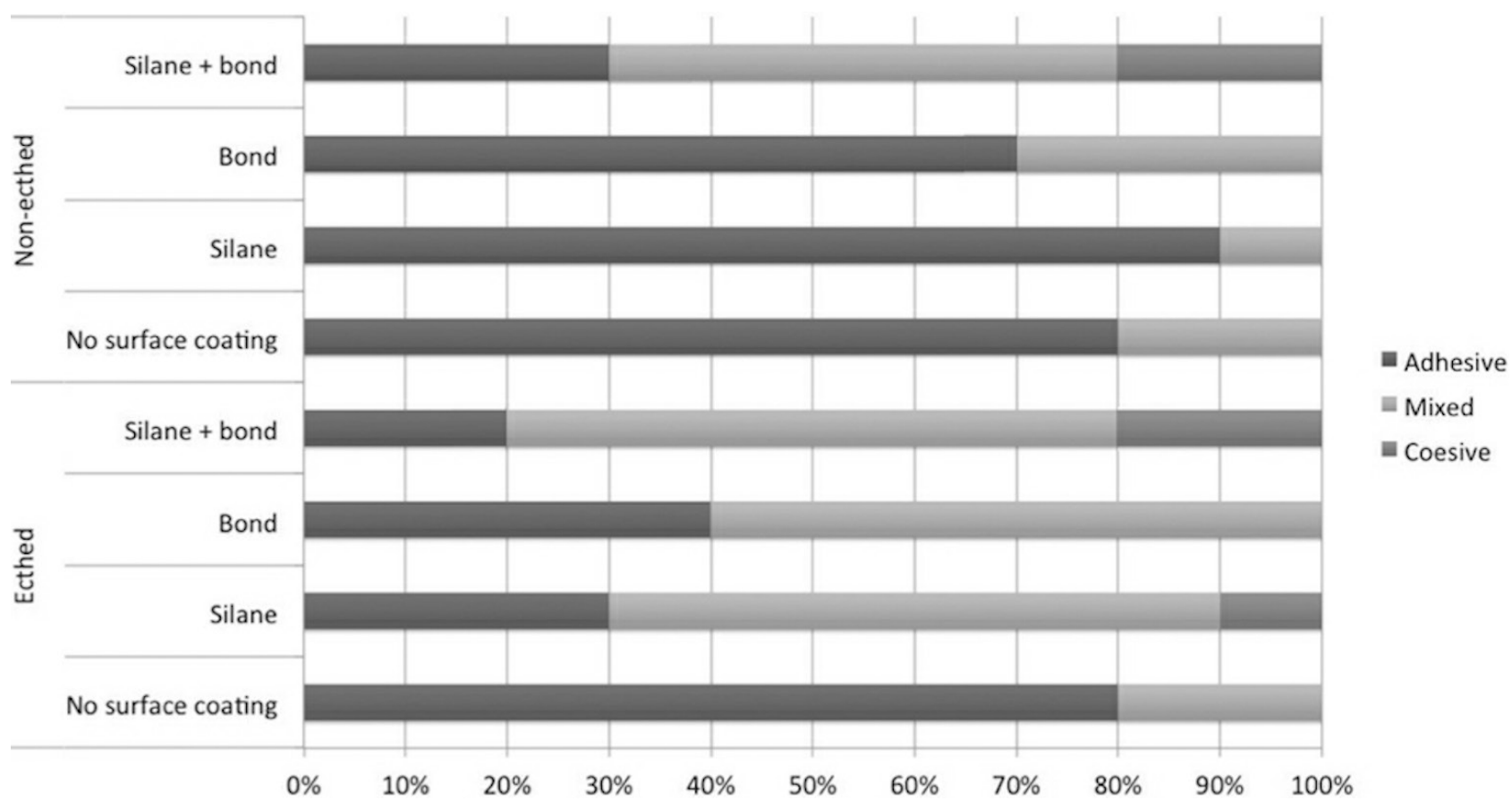

Figure 1. Distribution of failure modes (\%) among groups. 
microtensile bond test was introduced by Sano (22) in an attempt to eliminate the non-uniform stress distribution within the adhesive zone. With the loading stress more uniformly distributed, failures predominantly occur at the adhesive interface (23). In addition, multiple specimens can be obtained from a single unit, so the variance associated with this test is usually low (20\%), providing more consistent data. Microtensile bond strength test was preferred over shear bond strength test because with the latter, even though more frequently used, it is not possible to determine the actual stress generated at the interface. Microscopic analysis of the fractured areas should be performed to provide a more complete description of the failure modes when the microtensile bond test is used (23).

Generally the several surface treatments tested in this study improved the bond strength to GFPs. Regarding the surface etching by HP, the etched groups did not differ statistically from non-etched group, except to group surface coated by unfilled resin where the etching acid enhanced the bond strength, rejecting the first hypothesis. The SEM analysis showed the high amount of inorganic matrix present in GFPs. So, the etching acid for $15 \mathrm{~s}$ by
HP (37\%) may not be sufficient to remove a significant amount of matrix to create voids to be filled with silane and/or unfilled resin, enhancing the bond strength. SEM analysis also showed the formation of a thick adhesive layer between the post and resin composite for the unfilled resin non-etched group (Fig. 2B). This situation might explain the lower bond strength values found for this group. The association between $\mathrm{HP}$ and unfilled resin agent generated a thinner and more homogeneous adhesive layer on the GFP surface, decreasing the possibility of creating porosities without adversely affecting the bond strength. However, this phenomenon was not observed for other groups where silane (alone or combined with unfilled resin) was used as surface coating. The GFP surface acid etching can increase the surface energy and consequently improve the wettability by restorative materials. Maybe the unfilled resin is more sensitive to wettability caused by this treatment than silane. Despite the similar values of bond strength between etched and non-etched groups, the mode of failure was predominantly adhesive for the non-etched group, suggesting that this interface is the weak link in the adhesive system. This result shows the importance of
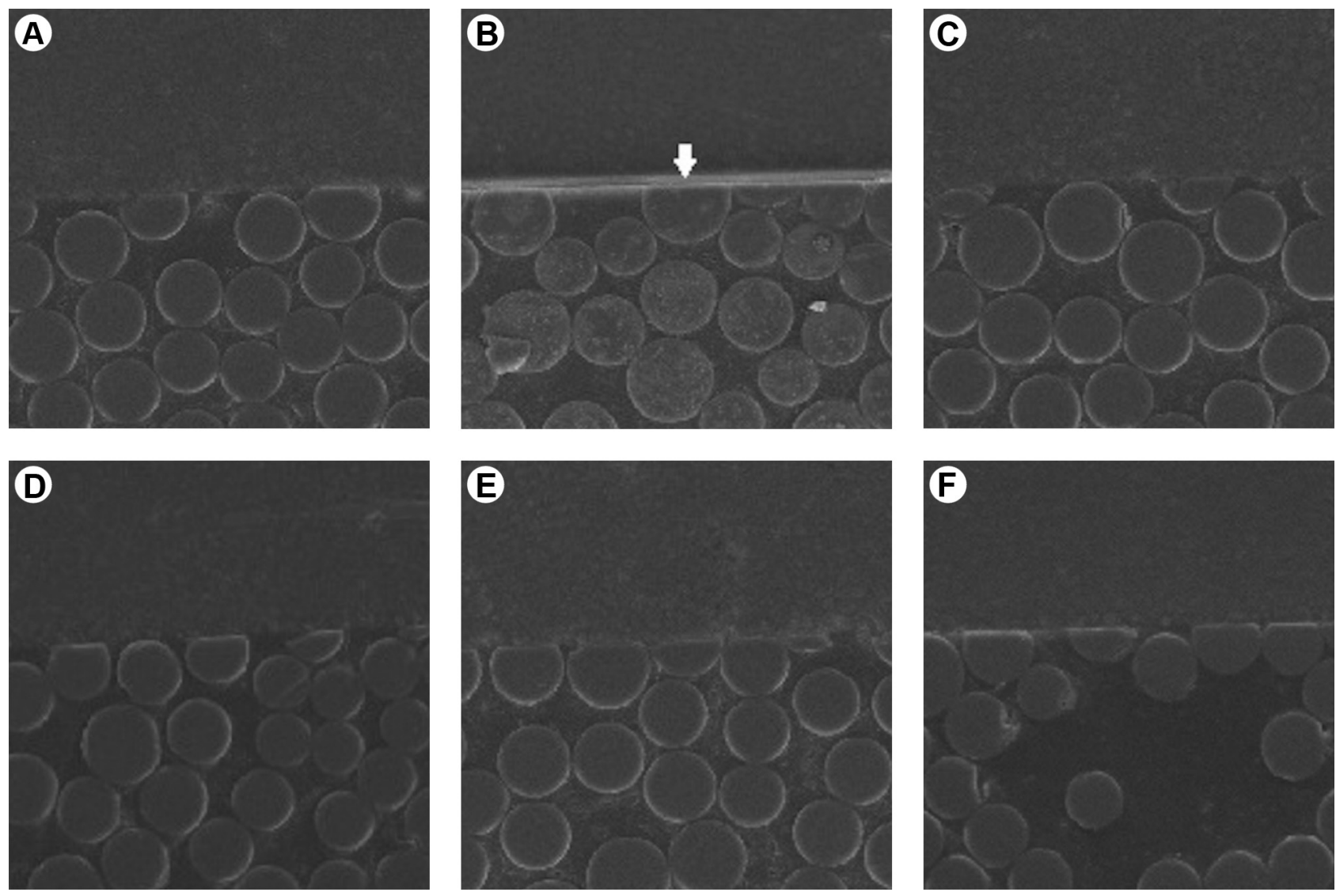

Figure 2. Representative SEM images $(15 \mathrm{kV}, 50 \mu \mathrm{m})$ of the bonded interfaces $(\mathrm{A}=$ only silane; $\mathrm{B}=$ only unfilled resin; $\mathrm{C}=$ silane + unfilled resin; $\mathrm{D}=\mathrm{HP}+$ silane; $\mathrm{E}=\mathrm{HP}+$ unfilled resin; $\mathrm{F}=\mathrm{HP}+$ silane + unfilled resin). The absence of HP etching when unfilled resin was used on surface coating formed a thick adhesive layer between the post and resin composite (arrow on B). No visible differences were observed for the other groups. 
acid etching on the GFP surface.

The second hypothesis was confirmed because the use of silane enhanced the bond strength to the GFPs. Silane solutions are hybrid organic-inorganic compounds which can establish adhesion between organic and inorganic matrices by an intrinsic dual reaction (24). Organosilanes bond to the silica in the GFPs through the formation of siloxane bonds after hydrolysis of the alkoxy groups into silanol groups, improving the surface wettability (24). Moreover, there is an intimate contact established between the interface materials, so the Van der Waals forces may become effective, providing a physical adhesion and contributing to the chemical reaction (25).

Application of unfilled resin also increased the bond strength, accepting the third hypothesis. The data shows that mechanical interlocking of this material with the GFP may have influence in improving the bond strength, besides of the chemical reaction. This phenomenon is clear observing the group where the association between silane and unfilled resin was used as surface coating treatment and generated higher bond strength than the use of silane alone. Chemical linkage through siloxane bonds, better surface wetting, and better mechanical keying are events $\dot{\sigma}$ that together may explain the highest values of bond strength for this group. Further, the use of silane only forms a non-homogeneous layer on the GFP surface, being unable to strengthen the surface by itself. The increase of the bond strength using only silane depends of its ability to fill the irregularities with resin composite. Together with unfilled resin they can both infiltrate the GFP surface and entangle the substrate, reinforcing its structure. A limitation of this study was the GFP surfaces were polished using silicon carbide papers to obtain flat surfaces prior to bonding procedures. The polishing was necessary due the original geometry of the specimens and it can have created a smoother surface compared to clinical situation. Further study can confirm this limitation.

This study showed that any surface coating material has the ability to improve the bond strength and that the best scenario is the combined use of silane and unfilled resin. Despite the etching with 37\% HP for $15 \mathrm{~s}$ did not increase the values of bond strength, the quality of the adhesive layer improved. Other variables such as different types of acid, concentration, and application times should be evaluated in further studies to define a protocol for surface treatments of GFPs.

\section{Resumo}

0 objetivo deste estudo foi avaliar o efeito resistência de união de uma resina composta para pinos de fibra de vidro (PFV) tratados ou não com ácido fosfórico, agente de união (silano) e adesivo. PFVs foram condicionados ou não com ácido fosfórico $37 \%$ e receberam aplicação de diferentes materiais: um agente de união, um adesivo, ou ambos.
Blocos em resina composta foram construídos a $4 \mathrm{~mm}$ de altura no PFV. 0 adesivo (20 s) e a resina composta (40 s) foram fotoativado por um diodo emissor de luz. As amostras foram armazenadas em água destilada a $37{ }^{\circ} \mathrm{C}$ por $24 \mathrm{~h}$. 0 teste de microtração foi realizado em uma máquina de ensaio universal $(n=10)$. Os dados foram analisados usando ANOVA dois fatores e teste de Student-Newman-Keuls $(p<0,05)$. Os padrões de fratura foram classificados em falhas adesivas, mistas ou coesivas. Amostras adicionais $(n=3)$ foram feitas para análise da interface de união em microscopia eletrônica de varredura. A análise estatística mostrou que o fator 'recobrimento da superficie' foi significante $(p<0,05)$, enquanto que o fator 'ácido fosfórico' $(p=0,131)$ e a interação entre os fatores $(p=0.171)$ não foram significantes. A maior resistência da união foi encontrada para os grupos silano e adesivo $(p<0,05)$. Uma predominância de falhas adesivas e coesivas foi encontrada. Foram observadas diferenças em relação à homogeneidade e espessura da camada adesiva formada sobre os PFV com os diferentes tratamentos de superfície. Aplicação de silano e adesivo pode melhorar a resistência de união entre PFV e resina composta.

\section{Acknowledgements}

The authors would like to thank Angelus for donating the glass-fiber posts.

\section{References}

1. Tamse A. Vertical root fractures in endodontically treated teeth: diagnostic signs and clinical management. Endod Topics 2006;13:84-94.

2. Khaledi AR, Sheykhian S, Khodaei A. Evaluation of retention of two different cast post-core systems and fracture resistance of the restored teeth. J Dent (Shiraz) 2015;16:121-128.

3. Saraiva LO, Aguiar TR, Costa L, Correr-Sobrinho L, Muniz L, Mathias P. Effect of different adhesion strategies on fiber post cementation: Pushout test and scanning electron microscopy analysis. Contemp Clin Dent 2013;4:443-447.

4. Faria-e-Silva AL, Menezes MS, Silva FP, Reis GR, Moraes RR. Intraradicular dentin treatments and retention of fiber posts with selfadhesive resin cements. Braz Oral Res 2013;27:14-19.

5. Goracci C, Fabianelli A, Sadek FT, Papacchini F, Tay FR, Ferrari M. The contribution of friction to the dislocation resistance of bonded fiber posts. J Endod 2005;31:608-612.

6. Liu C, Liu H, Qian YT, Zhu S, Zhao SO. The influence of four dual-cure resin cements and surface treatment selection to bond strength of fiber post. Int J Oral Sci 2014;6:56-60.

7. Balbosh A, Kern M. Effect of surface treatment on retention of glassfiber endodontic posts. J Prosthet Dent 2006;95:218-223.

8. Radovic I, Monticelli F, Goracci C, Cury AH, Coniglio I, Vulicevic ZR, et al. The effect of sandblasting on adhesion of a dual-cured resin composite to methacrylic fiber posts: microtensile bond strength and SEM evaluation. J Dent 2007;35:496-502.

9. Mosharraf R, Ranjbarian P. Effects of post surface conditioning before silanization on bond strength between fiber post and resin cement. J Adv Prosthodont 2013;5:126-132.

10. Davis P, Melo LS, Foxton RM, Sherriff M, Pilecki P, Mannocci F, et al. Flexural strength of glass fibre-reinforced posts bonded to dual-cure composite resin cements. Eur J Oral Sci 2010;118:197-201.

11. Faria MI, Gomes É, Messias DC, Silva Filho JM, Souza Filho CB, Paulino $\mathrm{SM}$. Tensile strength of glass fiber posts submitted to different surface treatments. Braz Dent J 2013;24:626-629.

12. Goracci $C$, Ferrari M. Current perspectives on post systems: a literature review. Aust Dent J 2011;56:77-83.

13. Lamichhane $A, X u C$, Zhang FQ. Dental fiber-post resin base material: a review. J Adv Prosthodont 2014;6:60-65.

14. Eames WB, Rogers LB, Feller PR, Price WR. Bonding agents for repairing porcelain and gold: an evaluation. Oper Dent 1977;2:118-124.

15. Aida M, Hayakawa T, Mizukawa K. Adhesion of composite to porcelain with various surface conditions. J Prosthet Dent 1995;73:464-470.

16. Novais VR, Simamotos Júnior PC, Rontani RM, Correr-Sobrinho $L$, Soares CJ. Bond strength between fiber posts and composite resin core: influence of temperature on silane coupling agents. Braz Dent J 2012;23:8-14. 
17. Perdigao J, Gomes G, Lee IK. The effect of silane on the bond strengths of fiber posts. Dent Mater 2006;22:752-758.

18. Moraes AP, Sarkis-Onofre R, Moraes RR, Cenci MS, Soares CJ, PereiraCenci T. Can silanization increase the retention of glass-fiber posts? A systematic review and meta-analysis of in vitro studies. Oper Dent 2015;40:567-580.

19. Naves LZ, Soares CJ, Moraes RR, Goncalves LS, Sinhoreti MA, CorrerSobrinho L. Surface/interface morphology and bond strength to glass ceramic etched for different periods. Oper Dent 2010;35:420-427.

20. Carvalho RM, Manso AP, Geraldeli S, Tay FR, Pashley DH. Durability of bonds and clinical success of adhesive restorations. Dent Mater 2012;28:72-86.

21. Steinhauser HC, Turssi CP, Franca FM, Amaral FL, Basting RT. Micro-shear bond strength and surface micromorphology of a feldspathic ceramic treated with different cleaning methods after hydrofluoric acid etching. J Appl Oral Sci 2014;22:85-90.
22. Sano H, Shono T, Sonoda H, Takatsu T, Ciucchi B, Carvalho R, et al.. Relationship between surface area for adhesion and tensile bond strength-evaluation of a micro-tensile bond test. Dent Mater 1994;10:236-240.

23. Della Bona A, Anusavice KJ, Mecholsky Jr JJ. Failure analysis of resin composite bonded to ceramic. Dent Mater 2003;19:693-699.

24. Matinlinna JP, Lassila LV, Ozcan M, Yli-Urpo A, Vallittu PK. An introduction to silanes and their clinical applications in dentistry. Int J Prosthodont 2004;17:155-164.

25. Pape PG, Plueddemann EP. Methods for improving the performance of silane coupling agents. J Adhes Sci Technol 1991;5:831-842.

Received December 20, 2015 Accepted March 8, 2016 